\title{
Faktor-Faktor yang Mempengaruhi Fenomena Audit Delay di Bursa Efek Indonesia
}

\author{
Luh Komang Adhika Wijasari ${ }^{1}$ \\ Fakultas Ekonomi dan Bisnis \\ Universitas Udayana, Indonesia
}

\author{
I Gde Ary Wirajaya ${ }^{2}$ \\ Fakultas Ekonomi dan Bisnis \\ Universitas Udayana, Indonesia
}

\begin{abstract}
Surel : wijasari.adhika@gmail.com
ABSTRAK

Laporan keuangan yang telah diaudit dipandang dapat diandalkan sumber informasi bagi pengguna informasi keuangan dalam rangka untuk mengambil keputusan-keputusan maka dari itu harus memperhatikan faktor-faktor yang mempengaruhi audit delay. Penelitian ini bertujuan untuk mengetahui pengaruh pergantian auditor, financial distress, reputasi KAP, dan pandemi covid-19 terhadap audit delay. Penelitian ini dilakukan pada perusahaan pertambangan yang terdaftar di Bursa Efek Indonesia periode 2017-2019. Jumlah sampel dalam penelitian ini sebanyak 105 perusahaan dengan menggunakan teknik nonprobability sampling. Regresi linier berganda terpilih sebagai teknik dalam menganalisis data. Berdasarkan hasil analisis diketahui bahwa audit delay tidak dipengaruhi oleh pergantian auditor, audit delay dipengaruhi secara positif oleh financial distress dan reputasi KAP berpengaruh negatif terhadap audit delay. Terdapat perbedaan signifikan audit delay sebelum masa pandemi covid-19 dan saat masa pandemi covid-19.
\end{abstract}

Kata Kunci: Audit Delay; Pergantian Auditor; Financial Distress; Reputasi KAP; Pandemi Covid-19.

\section{The Factors of Affecting the Audit Delay Phenomenon in the Indonesian Stock Exchange}

\begin{abstract}
Audited financial reports are considered a reliable source of information for users of financial information in order to make decisions, therefore they must pay attention to the factors that affect audit delay. This study aims to determine the effect of auditor switching, financial distress, KAP reputation, and the Covid-19 pandemic on audit delay. The study was carried out at the Indonesian Stock Exchange's mining firms for the period 2017-2019. The number of samples in this study were 105 companies using nonprobability sampling techniques. Multiple linear regression analysis is selected as the technique in analyzing the data. Based on the analysis, it is known that auditor switching has no effect on audit delay, financial distress has a positive effect on audit delay, and the reputation of KAP has a negative effect on audit delay. There is a significant difference in the audit delay before the Covid-19 pandemic and during the Covid-19 pandemic.
\end{abstract}

Keywords: Audit Delay; Auditor Switching; Financial Distress; Reputation of KAP; Pandemic Covid-19.

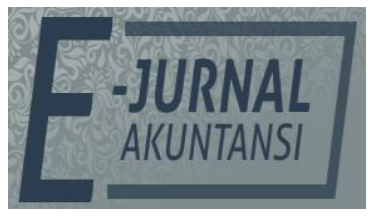

e-ISSN 2302-8556

Vol. 31 No. 1

Denpasar, Januari 2021 Hal. 168-181

DOI:

10.24843/EJA.2021.v31.i01.p13

PENGUTIPAN:

Wijasari, L.K.A., \& Wirajaya, I G.A.W. (2021). Faktor-

Faktor yang Mempengaruhi Fenomena Audit Delay di Bursa Efek Indonesia. EJurnal Akuntansi, 31(1), 168-

RIWAYAT ARTIKEL: Artikel Masuk: 12 November 2020 Artikel Diterima: 23 Januri 2021

Artikel dapat diakses : https://ojs.unud.ac.id/index.php/Akuntansi/index 


\section{PENDAHULUAN}

Audit delay adalah lamanya waktu penyelesaian audit yang diukur dari tanggal penutupan tahun buku sampai tanggal diselesaikannya laporan audit independen. Menurut Verawati \& Wirakusuma, (2016), lamanya waktu penyelesaian audit yang dilakukan mengindikasikan tentang waktu antara tanggal laporan keuangan dengan tanggal opini audit dalam laporan keuangan auditan. Di seluruh dunia, keterlambatan dalam audit laporan keuangan telah diidentifikasi sebagai salah satu yang menyebabkan keterlambatan keseluruhan dalam publikasi laporan tahunan mereka (Khoufi \& Khoufi, 2018). Satu-satunya sumber utama informasi yang dapat dipercaya oleh investor adalah laporan tahunan yang telah diaudit (Mathuva et al., 2019).

Tersedianya informasi yang berguna untuk sebagian besar kalangan pengguna laporan seperti posisi keuangan, kinerja, dan arus kas merupakan tujuan dari laporan keuangan (Diastiningsih \& Tenaya, 2017). Laporan keuangan harus dipublikasikan secara tepat waktu kepada pengguna ketika mereka membutuhkannya untuk membuat keputusan, karena informasi kehilangan manfaatnya jika tidak tersedia saat dibutuhkan (Ha et al., a2018). Terprediksinya performa perusahaan di masa mendatang dapat ditentukan oleh penyampaian informasi. Pentingnya penyampaian informasi yang efektif dalam memperkuat pelaporan perusahaan melalui pengiriman informasi keuangan yang tepat waktu ke pasar modal (Oussii \& Boulila Taktak, 2018a). Pada dasarnya, ketepatan waktu penyelesaian tugas audit menunjukkan bahwa auditor harus bekerja secara efisien tanpa mengabaikan keandalan informasi yang dihasilkan dalam laporan keuangan (Abdillah et al., 2019). Baatwah et al., (2019) menyatakan bahwa ketepatan waktu informasi keuangan dianggap sebagai elemen penting bagi pengambil keputusan, dan satu-satunya penentu paling penting oleh perusahaan dalam pelaporan keuangan adalah panjangnya proses audit.

Penyelesaian proses audit tergantung pada waktu yang diambil oleh auditor ekstrenal dalam publikasi informasi keuangan perusahaan. Akibatnya, ada tekanan pada auditor eksternal untuk menerbitkan laporan audit tanpa penundaan yang tidak semestinya (Oussii \& Boulila Taktak, 2018b). Laporan keuangan yang telah diaudit dipandang dapat diandalkan sumber informasi bagi pengguna informasi keuangan (Rusmin \& Evans, 2017). Hal terpenting bagi auditor adalah bagaimana agar pada saat menyampaikan laporan keuangan itu bisa tepat waktu atau tidak terlambat serta menjamin kerahasiaan informasi yang terkandung di dalam laporan keuangan tidak bocor kepada pihak lain (Pratiwi \& Wiratmaja, 2018). Abdulla, (1996) menyatakan bahwa jika perusahaan menunda mempublikasikan laporan keuangan auditan memungkinkan meningkatnya ketidakpastian terkait dengan keputusan yang akan dibuat oleh investor berdasarkan informasi yang diperoleh dari laporan keuangan tersebut. Karena dalam berinvestasi membutuhkan informasi yang benar, akurat, dan tepat waktu untuk dijadikan bahan dalam pengambilan keputusan.

Fenomena audit delay di Indonesia bukanlah hal yang baru. Terlepas dari adanya penetapan peraturan terkait penyampaian laporan keuangan, keterlambatan dalam penyampaian laporan keuangan yang telah teraudit masih kerap terjadi di beberapa perusahan. Berdasarkan informasi dari idx.co.id, BEI mengutarakan bahwa per 31 Desember 2017 terdapat 10 emiten yang terlambat 
dalam menyampaikan laporan keuangan audit dan per Desember 2018 juga ada 10 emiten yang melakukan hal serupa. PT Bursa Efek Indonesia (BEI) memberikan kelonggaran penyampaian batas waktu penyampaian laporan keuangan dan laporan tahunan terkait dengan kondisi pandemi covid-19 saat ini. Penyampaian laporan keuangan yang tidak tepat waktu semakin menjadi trend di kalangan emiten sehingga per 31 Desember 2019 BEI mendata adanya 64 emiten yang belum melaporkan keuangan audit (idx.co.id).

Memahami faktor-faktor yang mendasarinya audit delay akan memberikan wawasan tentang efisiensi audit. Selain itu, pemahaman mengenai penyebab keterlambatan audit dibutuhkan bagi investor dan regulator karena mereka sangat bergantung pada laporan keuangan perusahaan (Alfraih, 2016). Adapun faktor-faktor yang dapat mempengaruhi audit delay adalah pergantian auditor, kompleksitas operasi, kontinjensi, profitabilitas, financial distress, dewan komisaris independen, reputasi KAP, dan umur perusahaan (Fatimah \& Wiratmaja, 2018), (Dewi \& Suputra, 2017), (Praptika \& Rasmini, 2016), (Verawati \& Wirakusuma, 2016), (Pratiwi \& Wiratmaja, 2018), (Oktaviani \& Ariyanto, 2019), dan (Widhiasari \& Budiartha, 2016). Menurut Verawati \& Wirakusuma (2016), Praptika \& Rasmini (2016), dan Oktaviani \& Ariyanto (2019) dari beberapa variabel yang mempengaruhi audit delay, ada tiga variabel yang diduga paling memengaruhinya yaitu pergantian auditor, financial distress, dan reputasi KAP.

Kebijakan perusahaan dalam mengganti auditor ditujukan untuk memberhentikan kerjasama dengan auditor sehingga independensi dan objektivitas auditor dalam mengemban tugas tetap terjaga. Kontrak kerja yang sudah usai antara auditor dengan perusahaan klien merupakan salah satu penyebab pergantian auditor. Kemungkinan terjadinya audit delay bisa diakibatkan oleh kecenderungan auditor baru yang menghabiskan waktu lebih banyak dalam menelaah karakteristik perusahaan sebagai efek dari pergantian auditor (Dewi \& Suputra, 2017). Studi yang dilakukan oleh Verawati \& Wirakusuma, (2016) menyatakan bahwa pergantian auditor berpengaruh terhadap audit delay.

Faktor lain yang menyebabkan munculnya audit delay adalah financial distress. Financial distress atau kesulitan adalah suatu kondisi dimana keuangan perusahaan sedang dalam masalah, krisis atau tidak sehat yang terjadi sebelum perusahaan mengenai kebangkrutan (Listyaningsih \& Cahyono, 2018). Tingginya risiko audit cenderung dihadapi oleh perusahaan yang ada dalam situasi keuangan yang sulit sehingga berdampak pada semakin lamanya auditor mengkaji kembali akun-akun laporan atau dalam kata lain audit delay semakin bertambah panjang (Dellaportas et al., 2012). Penelitian Akhalumeh, (2017) mengungkapkan debt to total asset tidak berpengaruh pada audit delay. Di dalam penelitiannya, Muliantari \& Latrini, (2017) mengungkapkan adanya pengaruh financial distress pada audit delay.

Reputasi kantor akuntan publik juga dapat mempengaruhi audit delay. Pemberian informasi yang relevan dapat dilihat dari keakuratan serta reliabilitas laporan keuangan. Kantor Akuntan Publik (KAP) yang mempunyai reputasi baik beraliansi dengan KAP universal seperti Big Four. Dibandingkan dengan KAP Non-Big Four, audit yang dikerjakan oleh KAP Big Four mampu lebih awal terselesaikan (Verawati \& Wirakusuma, 2016). Kapabilitas, keterampilan dan 
profesionalisme sumber daya yang ada pada KAP Big Four mampu memperlancar proses audit sehingga audit delay pun berkurang. Verawati \& Wirakusuma, (2016) memperkuat penelitian ini dengan menemukan bahwa hasil reputasi KAP audit delay dipengaruhi secara negatif oleh hasil reputasi KAP.

Studi ini dilakukan karena adanya ketidakonsistenan yang terjadi pada hasil penelitian-penelitian sebelumnya. Maka dari itu, peneliti tertarik untuk meneliti kembali mengenai pengaruh pergantian auditor, financial distress, reputasi KAP, dan pandemi covid-19 pada audit delay. Penelitian ini menggunakan Perusahaan pertambangan yang masuk dalam daftar Bursa Efek Indonesia periode 2017-2019 terpilih dalam penelitian ini karena dianggap cukup dalam merepresentasikan kondisi perusahaan di Indonesia serta peningkatan yang dialami tiap tahunnya sebagai salah satu sektor yang memiliki andil penting dalam pertumbuhan ekonomi Indonesia. Alasan dipilihnya periode penelitian tahun 2017-2019 karena periode tersebut merupakan periode yang terbaru dibandingkan dengan penelitian-penelitian sebelumnya sehingga dapat memberikan gambaran terkini secara lebih akurat terhadap kinerja keuangan suatu perusahaan.

Pengujian efek pergantian auditor, financial distress, reputasi KAP, dan pandemi covid-19 pada audit delay menjadi tujuan diadakannya penelitian ini. Diharapkan pula agar penelitian ini mampu berkontribusi secara positif untuk manajemen perusahaan, auditor serta peneliti selanjutnya, penelitian ini dapat menjadi bahan rujukan acuan dalam menambah informasi terkait penelitian yang sejenis.

Jensen \& Meckling, (1976) menjelaskan bahwa sebagai salah satu upaya agency theory, pengaturan hak dan kewajiban kedua belah pihak membutuhkan kontrak kerja. Agen didefinisikan sebagai pihak yang berwenang dan bertanggung jawab dalam mengatur dan membuat keputusan perusahaan mempunyai keharusan dalam memberikan pertanggungjawaban berupa laporan keuangan yang sudah diaudit oleh auditor independen. Pelaksanaan beberapa pekerjaan oleh agen atas nama prinsipal yang mengikutsertakan pendelegasian wewenang penyusun keputusan diinstruksikan oleh prinsipal. Namun, perbedaan kepentingan dari kedua belah pihak menimbulkan konfrontasi dalam hubungan ini sehingga auditor sebagai pihak ketiga yang independen diperlukan agar tidak adanya penyalahgunaan kepercayaan oleh pihak agen yang telah diberi oleh prisipal. Berkurangnya asimetri informasi dapat disebabkan oleh ketepatwaktuan pelaporan keuangan (Yuniarti, 2018). Ketepatwaktuan dalam menyajikan laporan keuangan juga mampu menciptakan pengawasan dan kontrol yang maksimal dari pihak prinsipal ke agen, serta menjaga relevansi informasi dan nilai-nilai yang berperan dalam membuat keputusan. Teori kepatuhan mendorong perusahaan untuk melakukan pengiriman laporan keuangan tepat waktu, yang akan bermanfaat bagi pengguna laporan. Saputra, (2017) menyatakan bahwa teori kepatuhan berkaitan dengan upaya mendorong perilaku perusahaan agar menyampaikan laporan keuangan dengan tepat waktu yaitu melalui proses sosialisasi dan pemberlakuan peraturan yang ketat. Tuntutan akan kepatuhan terhadap ketepatan waktu dalam penyampaian laporan keuangan tahunan perusahaan publik di indonesia telah diatur dalam peraturan terbaru yang 
dikeluarkan oleh OJK (Otoritas Jasa Keuangan), yaitu peraturan Nomor: 29/POJK.04/2016 tentang Laporan tahunan emiten atau perusahaan publik.

Berkaitan dengan teori agensi, pentingnya keberadaan auditor yang independen dalam mengevaluasi kesesuaian kinerja manajemen dengan kehendak pemegang saham (principal) melalui laporan keuangan yang sudah disusun oleh pihak manajemen membuat tingkat kewajaran atas laporan tersebut dapat terukur serta auditor bisa berpendapat atas laporan keuangan perusahaan tersebut. Menurut Widhiasari \& Budiartha, (2016) sejalan dengan Arens et al., (2011) menyatakan setelah memahami alasan perusahaan untuk melakukan audit, auditor harus menyusun strategi pengauditan awal dengan memahami bisnis dan industri klien. Ketidaktepatan waktu penyampaian laporan keuangan sebagai akibat dari pergantian auditor oleh principal bisa dipengaruhi oleh tidak independennya sikap yang dimiliki oleh auditor dalam menilai kewajaran laporan. Verawati \& Wirakusuma, (2016) memaparkan bahwa audit delay dipengaruhi secara positif oleh pergantian auditor. Ini dikarenakan lebih lamanya alokasi waktu yang diperlukan oleh auditor baru untuk menggali informasi lebih dalam terkait karakteristik usaha klien beserta sistem didalamnya sehingga proses auditnya pun menjadi lebih lama. Hal ini berdampak pada penyampaian laporan keuangan auditan yang tertunda. Ratnaningsih \& Dwirandra, (2016), dan Praptika \& Rasmini, (2016) dalam penelitiannya menekankan bahwa audit delay dipengaruhi secara positif oleh pergantian auditor. Sedangkan penelitian yang dilakukan oleh Widhiasari \& Budiartha (2016), Fatimah \& Wiratmaja (2018), Perangin-angin (2019), dan Pratiwi \& Wiratmaja (2018) menyatakan bahwa pergantian auditor tidak berpengaruh terhadap audit delay. Berdasarkan uraian diatas, maka dirumuskan hipotesis sebagai berikut.

$\mathrm{H}_{1}$ : Pergantian auditor berpengaruh positif terhadap audit delay.

Financial distress sebagai salah satu bentuk kabar buruk bagi perusahaan mengakibatkan perusahaan mencari upaya terbaik dalam membenahi laporan keuangannya sehingga laporan keuangan yang diaudit akan tersampaikan lebih panjang (Chandra \& Bawono, 2018). Tingginya nilai rasio financial distress memberi pengaruh pada panjangnya audit delay. Berkaitan dengan teori agensi, prinsipal mempekerjakan agen untuk melaksanakan tugas termasuk pengambilan keputusan ekonomik, dalam lingkungan yang tidak pasti seperti perusahaan dalam kondisi financial distress, dimana kondisi tersebut disebabkan adanya perbedaan kepentingan antara agen dan prinsipal yang berujung pada konflik sehingga agen sering mengambil keputusan tidak dalam kepentingan terbaik prinsipal. Hal ini menyebabkan adanya pengawasan yang ditindak oleh auditor independen karena keinginan manajer untuk membenahi laporan keuangannya sehingga laporan keuangan yang diaudit akan tersampaikan lebih panjang Penelitian tersebut didukung oleh penelitian Muliantari \& Latrini, (2017) yang menyatakan bahwa audit delay dipengaruhi oleh financial distress secara positif dan signifikan. Penelitian Vuko \& Čular (2014), dan Sakka \& Jarboui (2016) memaparkan adanya pengaruh positif dari debt to total asset pada audit delay. Sedangkan penelitian yang dilakukan oleh Listyaningsih \& Cahyono, (2018) menyatakan tidak adanya pengaruh financial distress pada audit delay. Ditinjau dari pemaparan tersebut, terbentuklah hipotesis sebagai berikut.

$\mathrm{H}_{2}$ : Financial distress berpengaruh positif terhadap audit delay. 
Ahmad \& Kamarudin, (2003) menyatakan bahwa reputasi suatu KAP semakin membaik apabila proses auditnya semakin cepat sehingga memperkecil probabilitas terjadinya audit delay. Perbedaan kategori ukuran KAP yakni KAP the big four dan KAP non the big four menjadi penentu kualitas audit. Dibandingkan dengan KAP Non-Big Four, audit yang dikerjakan oleh KAP Big Four mampu lebih awal terselesaikan dan mampu berpendapat yang going concern (Verawati \& Wirakusuma, 2016). Kapabilitas, keterampilan dan profesionalisme sumber daya yang ada pada KAP Big Four mampu memperlancar proses audit sehingga audit delay pun berkurang. Verawati \& Wirakusuma, (2016) memperkuat penelitian ini dengan menemukan bahwa hasil reputasi KAP audit delay dipengaruhi secara negatif oleh hasil reputasi KAP. Oleh sebab itu, pendeknya waktu yang dibutuhkan dalam menyampaikan laporan keuangan auditan dipengaruhi oleh tingginya reputasi KAP sehingga probabilitas terjadinya audit delay pun berkurang. Berdasarkan uraian diatas, maka dirumuskan hipotesis sebagai berikut.

$\mathrm{H}_{3}$ : Reputasi kap berpengaruh negatif terhadap audit delay.

Pandemi Covid-19 dapat menyebabkan akuntan ataupun auditor tidak dapat merilis dan menyampaikan laporan keuangan tepat waktu. Hal tersebut dikarenakan meningkatnya risiko-risiko audit yang menyebabkan auditor harus melakukan pemeriksaan risiko (risk assessment). Hal ini bisa menimbulkan proses audit yang lama serta memberi dampak pada penyampaian laporan keuangan yang tidak tepat waktu. Terganggunya kapabilitas auditor dalam pencarian bukti audit yang cukup dan benar diakibatkan oleh terbatasnya akses, perjalanan serta ketersediaan personel karena pertimbangan kesehatan sehingga berdampak pada waktu untuk auditor dalam merilis dan menyampaikan laporan keuangan tepat waktu (iapi.or.id). Audit dengan mutu yang tinggi bisa terselesaikan dengan adanya penambahan waktu yang bisa berdampak pada deadline pelaporan. Berdasarkan uraian diatas, maka dirumuskan hipotesis sebagai berikut.

$\mathrm{H}_{4}$ : Terdapat perbedaan signifikan audit delay sebelum masa pandemi covid-19 dan saat masa pandemi covid-19.

\section{METODE PENELITIAN}

Penelitian ini menggunakan pendekatan kuantitatif yang berbentuk asosiatif, yaitu suatu penelitian yang memiliki tujuan untuk mencari tahu efek dari pergantian auditor, financial distress, reputasi KAP, dan pandemi covid- 19 pada audit delay. Penelitian ini dilakukan pada perusahaan pertambangan yang masih ada di dalam daftar Bursa Efek Indonesia selama periode 2017- 2019. Objek penelitian ini adalah pergantian auditor, financial distress, reputasi KAP, dan pandemi covid-19 terhadap audit delay selama periode 2017-2019 yang terdaftar di Bursa Efek Indonesia. Variabel independen dalam penelitian ini adalah audit delay yang dihitung berdasarkan jumlah hari tanggal tutup buku perusahaan (31 Desember) hingga tanggal yang tertera pada laporan auditor independen. Variabel bebas yang digunakan yaitu: Pergantian auditor diukur menggunakan variabel dummy. Apabila perusahaan melakukan pergantian auditor akan diberi kode 1, apabila tidak maka dilabeli kode 0. Eksistensi pergantian auditor dapat ditinjau melalui perbandingan nama auditor pada laporan keuangan auditan tahun ini dengan tahun sebelumnya; Financial distress diproksikan dengan DAR; 
Pengukuran pada reputasi KAP dilakukan dengan variabel dummy. Angka 1 diberikan pada perusahaan yang menggunakan jasa KAP yang berafiliasi dengan KAP The Big Four Auditor. Sedangkan angka 0 diberikan kepada perusahaan yang menggunakan jasa KAP yang tidak berafiliasi dengan KAP The Big Four Auditor. Adapun kategori Kantor Akuntan Publik yang berafiliasi dengan The Big Four di Indonesia (Sutikno \& Hadiprajitno, 2015) yaitu KAP Price Waterhouse Coopers, yang bekerja sama dengan KAP Tanudiredja, Wibisana \& Rekan; KAP KPMG (Klynveld Peat Marwick Goerdeler), yang bekerja sama dengan KAP Siddharta dan Widjaja; KAP Ernst $\mathcal{E}$ Young, yang bekerja sama dengan KAP Purwantono, Suherman dan Surja; KAP Deloitte Touche Tohmatsu, yang bekerja sama dengan KAP Osman Bing Satrio; Pengukuran pada pandemi Covid-19 dilakukan dengan variabel dummy. Perusahaan dalam periode 2019 diberi angka 1, sedangkan angka 0 diberikan kepada perusahaan dalam periode 2017 dan 2018.

Jenis data dalam penelitian ini adalah data kuantitatif yang berupa laporan keuangan tahunan dan laporan auditan perusahaan dan data kualitatif yang berupa daftar nama perusahaan yang digunakan sebagai sampel. Sumber data dalam penelitian ini adalah data sekunder berupa laporan tahunan perusahaan pertambangan yang terdaftar di BEI tahun 2017-2019 dan data diperoleh dari website Bursa Efek Indonesia yaitu www.idx.go.id. Penelitian ini meneliti seluruh perusahaan pertambangan yang terdaftar di BEI selama periode 2017-2019 sebagai populasi dan menggunakan metode metode nonprobability sampling dengan teknik sampling jenuh, yaitu teknik penentuan sampel bila semua anggota populasi dijadikan sampel sehingga jumlah sampel total dengan periode pengamatan 3 tahun yaitu 105 perusahaan.

Pengaruh pergantian auditor, financial distress, reputasi KAP, dan pandemi covid-19 terhadap audit delay dapat diketahui dengan menggunakan teknik analisis regresi linier berganda dengan persamaan sebagai berikut.

$\mathrm{Y}=\alpha 0+\beta 1 X_{1}+\beta_{2} X_{2}+\beta_{3} X_{3}+\varepsilon$

Keterangan:

Y : Audit Delay

a0 : Konstansta

$\beta \quad$ : Koefisien Regresi

$\mathrm{X}_{1} \quad$ : Pergantian Auditor

$\mathrm{X}_{2} \quad$ : Financial Distress

$\mathrm{X}_{3} \quad$ : Reputasi KAP

$\varepsilon \quad:$ Standar Error

\section{HASIL DAN PEMBAHASAN}

Gambaran umum perusahaan menjelaskan mengenai situasi umum perusahaan yang diteliti. Penelitian ini menggunakan populasi seluruh perusahaan pertambangan yang terdaftar di Bursa Efek Indonesia (BEI) periode 2017-2019. Pemilihan sampel dengan metode nonprobability sampling dengan sampling jenuh yaitu yaitu teknik penentuan sampel bila semua anggota populasi dijadikan sampel. Proses penentuan sampel dengan metode nonprobability sampling yang disajikan pada Tabel 1. 
Tabel 1. Proses Penentuan Sampel

\begin{tabular}{llc}
\hline No. & Kriteria & Jumlah \\
\hline $1 . \quad \begin{array}{l}\text { Perusahaan pertambangan yang terdaftar di Bursa Efek Indonesia } \\
\text { periode 2017-2019 }\end{array}$ & 50 \\
2. $\quad \begin{array}{l}\text { Perusahaan pertambangan yang tidak menampilkan data yang } \\
\text { diperlukan secara lengkap }\end{array}$ & $(12)$ \\
$\quad$ Jumlah perusahaan sampel Data Outlier & 38 \\
& $(3)$ \\
Jumlah pengamatan penelitian & 35 \\
Tahun pengamatan & 3 \\
Total sampel penelitian selama periode pengamatan & 105 \\
\hline
\end{tabular}

Sumber: Data Penelitian, 2020

Berdasarkan Tabel 1, dapat diketahui bahwa jumlah populasi penelitian ini sebanyak 50 perusahaan pertambangan yang terdaftar di Bursa Efek Indonesia (BEI) sampai saat ini, namun terdapat 12 perusahaan pertambangan yang datanya tidak ditemukan dalam website resmi www.idx.co.id serta data outlier sebanyak 3 data perusahaan dikeluarkan dari sampel karena nilai dari audit delay muncul dengan nilai-nilai ekstrim. Sehingga diperoleh total sampel penelitian selama periode pengamatan sebanyak 105 perusahaan.

Tabel 2. Hasil Analisis Statistik Deskriptif Variabel Penelitian

\begin{tabular}{cccccc}
\hline & $\mathrm{N}$ & Minimum & Maximum & Mean & Std. Deviation \\
\hline $\mathrm{X}_{1}$ & 105 & 0,00 & 1,00 & 0,505 & 0,502 \\
$\mathrm{X}_{2}$ & 105 & 0,007 & 1,408 & 0,527 & 0,262 \\
$\mathrm{X}_{3}$ & 105 & 0,00 & 1,00 & 0,400 & 0,492 \\
$\mathrm{Y}$ & 105 & 31,00 & 205,00 & 88,819 & 34,725 \\
Valid N (listwise) & 105 & & & & \\
\hline Sumber: Data Penelitian, 2020 & & &
\end{tabular}

Statistik deskriptif pada Tabel 2, menunjukkan bahwa Variabel Audit Delay (Y) mempunyai skor minimum 31,00, skor maksimum 205,00, dan rerata 88,819. Skor tersebut dapat diartikan bahwa dari 105 data diketahui audit delay minimum perusahaan yakni 31,00 hari sedangkan audit delay maksimum yakni 205,00 hari dengan rerata audit delay 88 hari yang dimana belum melebihi 120 hari sebagai batasan yang ditetapkan oleh OJK. Standar deviasi menunjukan angka 34,725 artinya, terjadi perbedaan nilai audit delay yang diteliti terhadap nilai rata-ratanya sebesar 34,725.

Variabel pergantian auditor memiliki nilai minimum sebesar 0 dan nilai maksimum sebesar 1 . Hal ini dikarenakan peneliti menggunakan pengukuran dummy dalam mengkuantitatifkan variabel pergantian auditor. Nilai rata-rata variabel pergantian auditor lebih besar dari standar deviasinya menunjukan bahwa pergantian auditor dengan kode 1 lebih banyak muncul dari 105 sampel yang diteliti atau hanya 52 perusahaan pertambangan yang tidak melakukan pergantian auditor dan 53 perusahaan melakukan pergantian auditor. Standar deviasi menunjukan angka 0,5024 artinya, terjadi perbedaan nilai pergantian auditor yang diteliti terhadap nilai rata-ratanya sebesar 0,5024.

Variabel financial distress memiliki nilai minimum sebesar 0,007, nilai maksimum sebesar 1,408, nilai rata-rata sebesar 0,527 serta standar deviasi 0,262. Nilai tersebut menggambarkan bahwa semua nilai financial distress dari 105 data perusahaan dalam daftar Bursa Efek Indonesia yang terpilih menjadi sampel 
penelitian mempunyai skor paling rendah yakni 0,007 , skor terbesar sebesar 1,408, dan rata-rata financial distress adalah sebesar 0,527. Standar deviasi menunjukan angka 0,262 artinya, terjadi perbedaan nilai financial distress yang diteliti terhadap nilai rata-ratanya sebesar 0,262 .

Variabel reputasi KAP memiliki nilai minimum sebesar 0 dan nilai maksimum sebesar 1 . Hal ini dikarenakan peneliti menggunakan pengukuran dummy dalam mengkuantitatifkan variabel reputasi KAP. Nilai rata-rata variabel reputasi KAP lebih kecil dari standar deviasinya menunjukan bahwa reputasi KAP dengan kode 0 lebih banyak muncul dari 105 sampel yang diteliti atau hanya 42 perusahaan pertambangan yang menggunakan jasa KAP yang berafiliasi dengan KAP The Big Four dan 63 perusahaan tidak menggunakan jasa KAP yang berafiliasi dengan KAP The Big Four. Standar deviasi menunjukan angka 0,492 berarti dismilaritas skor reputasi KAP yang diteliti pada skor reratanya yakni 0,492 .

Pengujian asumsi klasik adalah uji pendahuluan sebelum dilakukannya analisis regresi. Kolmogorov-Smirnov terseleksi menjadi model statistik pengujian normalitas dalam studi ini. Di dalam pengujian ini, diperoleh nilai KolmogorovSmirnov 0,200 serta tidak signifikan pada 0,05 (karena $\rho=0,200>0,05$ ). Sehingga bisa ditarik kesimpulan bahwasannya residual berdistribusi dengan normal.

Pengujian Durbin-Watson (DW-test) diaplikasikan dalam menguji autokorelasi. Hasil pengujian memperlihatkan 1,891 skor Durbin Watson. Skor D$\mathrm{W}$ berdasarkan table dengan $\mathrm{n}=105$ dan $\mathrm{k}=3$ meraih skor $\mathrm{dl}=1,62$ dan skor $\mathrm{du}=$ 1,74 . Oleh sebab itu, skor $d u<d w<(4-d u) \quad(1,74<1,891<2,26)$ dapat disimpulkan sebagai ketiadaan autokorelasi antar residual.

Skor tolerance dan VIF menjadi acuan dari pengujian multikolinieritas. Berdasarkan pengujian tersebut, bisa ditinjau bahwa pergantian auditor, financial distress, serta reputasi KAP, bernilai Tolerance melebihi 0,1 dan skor VIF tidak lebih dari 10. Maka, kesimpulan yang bisa ditarik yakni tidak ditemukan adanya gejala multikolinearitas pada model analisis tersebut.

Uji heteroskedastisitas dikategorikan sebagai model regresi yang baik apabila level signifikansinya melebihi level kepercayaan yakni 5\% $(0,05)$. Setelah diuji, semua nilai melebihi $a=0,05$ diantaranya signifikansi pergantian auditor sebanyak 0,593, financial distress sebanyak 0,647, dan reputasi KAP sebanyak 0,367. Ini berarti heteroskedastisitas tidak terjadi. Regresi linier berganda diaplikasikan sebagai teknis untuk menganalisis data.

Tabel 3. Rangkuman Hasil Analisis Regresi Linier Berganda

\begin{tabular}{ccccccc}
\hline & \multicolumn{4}{c}{ Unstandardized Coefficients } & Standardized Coefficients & \\
\cline { 3 - 5 } Model & $\mathrm{B}$ & Std. Error & Beta & T & Sig. \\
\hline 1 & (Constant) & 65,989 & 9,589 & & 6,875 & 0,000 \\
& $\mathrm{X}_{1}$ & 7,685 & 6,036 & 0,111 & 1,273 & 0,206 \\
& $\mathrm{X}_{2}$ & 46,164 & 13,144 & 0,348 & 3,512 & 0,001 \\
& $\mathrm{X}_{3}$ & $-13,919$ & 6,990 & $-0,197$ & $-2,027$ & 0,045 \\
& F hitung & $: 10,084$ & & & & \\
& Sig. F & $: 0,000$ & & & & \\
& R Square & $: 0,230$ & & & &
\end{tabular}

Sumber: Data Penelitian, 2020 


$$
\mathrm{Y}=63,984+4,839 \mathrm{X} 1+44,159 \mathrm{X} 2-13,919 \mathrm{X} 3+\varepsilon
$$

Tabel 3, memperlihatkan skor $F$ hitung sebanyak 10,084 disertai signifikansi $\mathrm{P}$ value 0,000 yang dibawah dari $\alpha=0,05$, ini mengindikasikan bahwa model yang diaplikasikan pada studi ini layak.

Tabel 3, menunjukan nilai Adjust $R$ Square sebesar 0,208 memiliki arti bahwa variasi audit delay dapat dipengaruhi oleh variabel pergantian auditor, financial distress, reputasi kap.

Tabel 3, menerangkan bahwa koefisien regresi pergantian auditor bernilai 7,685 dengan level signifikansi 0,206 melebihi taraf nyata $a=0,05$. Ini mengindikasikan bahwasannya, secara statistik, audit delay tidak dipengaruhi oleh pergantian auditor sehingga $\mathrm{H}_{1}$ ditolak. Maka kecepatan proses audit terselesaikan tidak ditentukan oleh pergantian auditor. Ini disebabkan oleh niat dan usaha auditor dalam menjaga reputasi serta KAPnya dalam mengaudit sebuah perusahaan sehingga meskipun baru, auditor cenderung memaksimalkan proses audit agar selesai dengan cepat. Apabila tidak demikian, kemungkinan turunnya reputasi auditor tersebut meningkat sehingga bisa memberi dampak pada kepercayaan klien. Selain itu, keputusan penerimaan klien dibuat oleh auditor dalam kurun waktu enam hingga sembilan bulan sebelum tahun fiskal berakhir sehingga auditor memiliki banyak waktu untuk mempersiapkan perencanaan yang matang sebelum melakukan pengujian. Hasil penelitian ini mendukung penelitian-penelitian sebelumnya yang dilakukan oleh Widhiasari \& Budiartha (2016), Fatimah \& Wiratmaja (2018), Perangin-angin (2019), Pratiwi \& Wiratmaja (2018) yang menyatakan bahwa pergantian auditor tidak berpengaruh terhadap audit delay.

Tabel 3, memaparkan koefisien regresi financial distress bernilai 46,164 dengan level signifikansi 0,001 dibawah taraf nyata $a=0,05$. Hasil ini menggambarkan adanya pengaruh positif yang diberikan oleh financial distress pada audit delay, sehingga bisa dikatakan bahwa $\mathrm{H}_{2}$ diterima. Maka, tingginya skor rasio financial distress berdampak pada audit delay yang semakin panjang. Financial distress sebagai salah satu bentuk kabar buruk bagi perusahaan mengakibatkan perusahaan mencari upaya terbaik dalam membenahi laporan keuangannya sehingga laporan keuangan yang diaudit akan tersampaikan lebih panjang (Kusuma, 2018). Hasil penelitian ini mendukung teori keagenan yaitu perusahaan yang dalam kondisi financial distress disebabkan karena adanya konflik kepentingan karena adanya perbedaan kepentingan antara agen dan prinsipal sehingga agen sering mengambil keputusan tidak dalam kepentingan terbaik prinsipal. Hal ini menyebabkan auditor independen melakukan pengawasan atau monitoring karena manajer berkeinginan untuk menyajikan laporan keuangan agar tampak lebih baik dari kondisi tersebut, sehingga penyampaian laporan keuangan yang diaudit akan lebih panjang. Hasil penelitian ini mendukung penelitianpenelitian sebelumnya yang dilakukan oleh (Sakka \& Jarboui 2016), (Muliantari \& Latrini 2017), (Praptika \& Rasmini 2016), dan (Oktaviani \& Ariyanto 2019) yang menyatakan bahwa financial distress berpengaruh positif terhadap audit delay.

Tabel 3, memaparkan koefisien regresi reputasi KAP bernilai $-13,919$ dengan level signifikansi sebanyak 0,045 dibawah taraf nyata $a=0,05$. Ini mengindikasikan bahwasannya bahwa hasil reputasi KAP audit delay dipengaruhi 
secara negatif oleh hasil reputasi KAP, itu berarti $\mathrm{H}_{3}$ diterima. Kantor Akuntan Publik (KAP) yang mempunyai reputasi baik beraliansi dengan KAP universal seperti Big Four. Dibandingkan dengan KAP Non-Big Four, audit yang dikerjakan oleh KAP Big Four mampu lebih awal terselesaikan (Verawati \& Wirakusuma 2016). Kapabilitas, keterampilan dan profesionalisme sumber daya yang ada pada KAP Big Four mampu memperlancar proses audit sehingga audit delay pun berkurang. KAP yang bereputasi baik cenderung menyelesaikan laporan keuangan dengan tepat waktu agar pandangan public terhap KAP tetap terjaga. Hasil studi ini diperkuat oleh teori kepatuhan yakni semakin baik reputasi KAP yang terpilih untuk menjalankan audit laporan keuangan maka KAP tersebut sudah berpengalaman dan memiliki pemahaman mengenai peraturan-peraturan yang berlaku sehingga laporan keuangan dapat dipublikasikan secara tepat waktu. Dengan adanya teori ini diharapkan perusahaan dapet menghindari terjadinya audit delay. Hasil penelitian ini mendukung penelitian sebelumnya yang dilakukan oleh Verawati \& Wirakusuma (2016) yang menyatakan bahwa reputasi kantor akuntan publik berpengaruh negatif terhadap audit delay.

Dalam penelitian ini, uji beda dilakukan untuk mengetahui adanya perbedaan audit delay sebelum masa pandemi covid-19 dan pada masa pandemi covid-19. Hasil pengujian (T-test) dapat dilihat pada Tabel 4.

Tabel 4. Hasil Uji Beda (T-Test)

\begin{tabular}{llcccc}
\hline & Periode & $\mathrm{N}$ & Mean & Std. Deviation & Std. Error Mean \\
\hline $\begin{array}{l}\text { Audit } \\
\text { delay }\end{array}$ & $\begin{array}{l}\text { Sebelum masa } \\
\text { pandemic }\end{array}$ & 70 & 83,286 & 31,390 & 3,752 \\
& $\begin{array}{l}\text { Masa Pandemi } \\
\text { Masa Pan }\end{array}$ & 35 & 99,886 & 38,726 & 6,545 \\
\hline
\end{tabular}

Sumber: Data Penelitian, 2020

Tabel 4, menunjukan nilai dari audit delay sebelum masa pandemi covid-19 memiliki rata-rata sebesar 83,286 dan standar deviasi sebesar 31,390. Sedangkan nilai dari audit delay saat masa pandemi covid-19 memiliki rata-rata sebasar 99,886 dan standar devisasi sebesar 38,726. Hal ini berarti terjadi perbedaan audit delay pada masa sebelum pandemi covid-19 dan saat masa pandemi covid-19. Dimana rata-rata audit delay saat masa pandemi covid-19 lebih besar dibandingkan sebelum masa pandemi covid-19. Maka, terdapat perbedaan yang signifikan saat masa pandemi covid-19 dan sebelum masa pandemi covid-19. Sebelum adanya pandemi covid-19 dalam hal untuk memperoleh bukti audit dapat dilakukan dengan cara menemui klien secara langsung untuk meminta data, meminta konfirmasi ke berbagai pihak yang berhubungan dengan klien, menulusuri buktibukti pencatatan ke kantor klien dan tentunya meeting dengan dewan direksi klien. Namun semua berubah di kala pandemi covid-19 dimana semua dilakukan dengan menggunakan audit jarak jauh, bertemu klien secara virtual dengan menggunakan online meeting, group video call, selanjutnya meminta konfirmasi dengan menggunakan cara virtual baik menggunakan email dan aplikasi personal chat, begitu pun untuk penelurusuran bukti-bukti pencatatan yang bisa di remote oleh aplikasi desktop dan pastinya meeting dengan dewan direksi pun dilaksanakan secara online atau virtual dengan berbagai aplikasi meeting yang ada. 


\section{SIMPULAN}

Berdasarkan hasil analisis data yang dilakukan maka diperoleh simpulan yaitu pergantian auditor tidak berpengaruh terhadap audit delay, financial distress berpengaruh positif terhadap audit delay, reputasi KAP berpengaruh negatif terhadap audit delay dan terdapat perbedaan signifikan audit delay sebelum masa pandemi covid-19 dan saat masa pandemi covid-19. Peneliti selanjutnya disarankan untuk meneliti kembali faktor-faktor lain yang mempengaruhi audit delay dengan jangka waktu penelitian yang lebih panjang untuk melihat efek variabel lainnya pada audit delay.

Laporan keuangan yang lengkap dan mampu terselesaikan tepat waktu sesuai regulasi yang ada menjadi harapan yang penting dilakukan bagi perusahaan guna memperlancar proses audit. Meskipun dalam keadaan keuangan yang sangat sulit, auditor disarankan untuk tetap menjaga ketepatwaktuan pelaporan audit agar sesuai dengan ketentuan yang telah ditetapkan oleh Otoritas Jasa Keuangan (OJK).

\section{REFERENSI}

Abdillah, M. R., Mardijuwono, A. W., \& Habiburrochman, H. (2019). The effect of company characteristics and auditor characteristics to audit report lag. Asian Journal of Accounting Research, 4(1), 129-144. https:/ / doi.org/10.1108/ajar-052019-0042

Abdulla, J. Y. A. (1996). The timeliness of Bahraini annual reports. Advances in International Accounting, 9, 73-88.

Ahmad, R. A. R., \& Kamarudin, K. A. (2003). Audit delay and the timeliness of corporate reporting: Malaysian evidence. Communication Hawaii International Conference on Business. June, University of Hawaii-West Oahu.

Akhalumeh, P. B. (2017). Firm characteristics and audit report delay in Nigeria.

Alfraih, M. M. (2016). Corporate governance mechanisms and audit delay in a joint audit regulation. Journal of Financial Regulation and Compliance, 24(3), 292-316. https://doi.org/10.1108/JFRC-09-2015-0054

Arens, A., Elder, R. J., Beasley, M. S., \& Jusuf, A. A. (2011). Auditing dan Jasa Assurance Pendekatan Terpadu. Jilid.

Baatwah, S. R., Salleh, Z., \& Stewart, J. (2019). Audit committee chair accounting expertise and audit report timeliness: The moderating effect of chair characteristics. Asian Review of Accounting, 27(2), 273-306. https://doi.org/10.1108/ARA-12-2017-0190

Bursa Efek Indonesia. Pengumuman Penyampaian Laporan Keuangan Auditan yang Berakhir per31 Desember 2017, 2018, dan 2019. Diakses pada 2 Juli 2020, dari www.idx.co.id

Chandra Kusuma, B., \& Bawono, A. D. B. (2018). Ukuran Perusahaan Sebagai Variabel Moderasi Pengaruh Profitabilitas, Financial Distress, dan Kepemilikan Publik Terhadap Audit Report Lag (Studi Empiris Pada Perusahaan Manufaktur yang Terdaftar di BEI Periode 2013-2016). Universitas Muhammadiyah Surakarta.

Dellaportas, S., Leung, P., Cooper, B. J., Ika, S. R., \& Ghazali, N. A. M. (2012). Audit committee effectiveness and timeliness of reporting: Indonesian evidence. Managerial Auditing Journal.

Dewi, G. A. N. P., \& Suputra, I. D. G. D. (2017). Pengaruh Kompleksitas Operasi, 
Kontinjensi, Pergantian Auditor pada Audit Report Lag dengan Spesialisasi Auditor sebagai Pemoderasi. E-Jurnal Akuntansi, 21, 912-941. https://doi.org/10.24843/EJA.2017.v21.i02.p02

Diastiningsih, N. P. J., \& Tenaya, G. A. I. (2017). Spesialisasi Auditor Sebagai Pemoderasi Pengaruh Audit Tenure Dan Ukuran Kap Pada Audit Report Lag. E-Jurnal Akuntansi, 18, 1230-1258.

Fatimah, S., \& Wiratmaja, I. D. N. (2018). Kompleksitas Operasi Perusahaan sebagai Pemoderasi Pengaruh Pergantian Auditor dan Financial Distress terhadap Audit Delay. E-Jurnal Akuntansi, 25, 1205. https://doi.org/10.24843/eja.2018.v25.i02.p15

Ha, H. T. V., Hung, D. N., \& Phuong, N. T. T. (2018). The study of factors affecting the timeliness of financial reports: The experiments on listed companies in Vietnam. Asian Economic and Financial Review, 8(2), 294-307. https://doi.org/10.18488/journal.aefr.2018.82.294.307

Jensen, M. C., \& Meckling, W. H. (1976). Theory of the firm: Managerial behavior, agency costs and ownership structure. Journal of Financial Economics. https:// doi.org/10.1016/0304-405X(76)90026-X

Khoufi, N., \& Khoufi, W. (2018). An empirical examination of the determinants of audit report delay in France. Managerial Auditing Journal, 33(8-9), 700-714. https://doi.org/10.1108/MAJ-02-2017-1518

Listyaningsih, D. F., \& Cahyono, Y. T. (2018). Pengaruh Karakteristik Perusahaan Dan Financial Distress Terhadap Audit Delay ( Studi Empiris Perusahaan Manufaktur Terdaftar di BEI ). Seminar Nasional Dan Call for Paper III Fakultas Ekonomi, 67-78.

Mathuva, D. M., Tauringana, V., \& Owino, F. J. O. (2019). Corporate governance and the timeliness of audited financial statements: The case of Kenyan listed firms. Journal of Accounting in Emerging Economies, 9(4), 473-501. https:// doi.org/10.1108/JAEE-05-2018-0053

Muliantari, N. P. I. A., \& Latrini, M. Y. (2017). Ukuran Perusahaan Sebagai Pemoderasi Pengaruh Profitabilitas Dan Financial Distress Terhadap Audit Delay Fakultas Ekonomi dan Bisnis Universitas Udayana ( Unud ), Bali , Indonesia Fakultas Ekonomi dan Bisnis Universi. E-Jurnal Akuntansi, 20(3), 1875-1903.

Oktaviani, N. P. S., \& Ariyanto, D. (2019). Pengaruh Financial Distress, Ukuran Perusahaan, dan Corporate Governance pada Audit Delay Ni. E-Jurnal Akuntansi, 27(3), 2154-2182.

Oussii, A. A., \& Boulila Taktak, N. (2018a). Audit committee effectiveness and financial reporting timeliness: The case of Tunisian listed companies. African Journal of Economic and Management Studies, 9(1), 34-55. https://doi.org/10.1108/ AJEMS-11-2016-0163

Oussii, A. A., \& Boulila Taktak, N. (2018b). Audit report timeliness: Does internal audit function coordination with external auditors matter? Empirical evidence from Tunisia. EuroMed Journal of Business, 13(1), 60-74. https://doi.org/10.1108/EMJB-10-2016-0026

Perangin-angin, D. S. B. (2019). Pengaruh Solvabilitas, Pergantian Auditor dan Opini Auditor Terhadap Audit Delay. Jurnal Akuntansi, 1(1), 92-95.

Peraturan Otoritas Jasa Keuangan Nomor 29/POJK.04/2016 Tentang Laporan 
Tahunan Emiten dan Perusahaan Publik

Peraturan Otoritas Jasa Keuangan Nomor 29/POJK.04/2016 Tentang Laporan Tahunan Emiten dan Perusahaan Publik

Praptika, P., \& Rasmini, N. (2016). Pengaruh Audit Tenure, Pergantian Auditor Dan Financial Distress Pada Audit Delay Pada Perusahaan Consumer Goods. E-Jurnal Akuntansi, 15(3), 2052-2081.

Pratiwi, C. I. E., \& Wiratmaja, I. D. N. (2018). Pengaruh Audit Tenure dan Kompleksitas Operasi Terhadap Audit Delay Perusahaan Pertambangan di BEI Tahun 2013-2016. E-Jurnal Akuntansi, 24, 1964. https://doi.org/10.24843/ eja.2018.v24.i03.p12

Ratnaningsih, N., \& Dwirandra, A. (2016). Spesialisasi Auditor Sebagai Variabel Pemoderasi Pengaruh Audit Tenure Dan Pergantian Auditor Pada Audit Delay. E-Jurnal Akuntansi, 16(1), 18-44.

Rusmin, R., \& Evans, J. (2017). Audit quality and audit report lag: case of Indonesian listed companies. Asian Review of Accounting.

Sakka, I. F., \& Jarboui, A. (2016). Audit reports timeliness: Empirical evidence from Tunisia. Cogent Business \& Management, 3(1), 1195680.

Saputra, I. K. W. S. (2017). Pengaruh Profitabilitas Dan Ukuran Perusahaan Terhadap Ketepatan Waktu Pelaporan Keuangan Dengan Opini Audit Sebagai Pemoderasi. E-Jurnal Akuntansi, 20(2), 1592-1620. https:// doi.org/10.24843/EJA.2017.v20.i02.p26

Verawati, N. M. A., \& Wirakusuma, M. G. (2016). Pengaruh Pergantian Auditor, Reputasi Kap, Opini Audit, Dan Komite Audit Dalam Audit Delay. E-Jurnal Akuntansi, 17(2), 1083-1111.

Vuko, T., \& Čular, M. (2014). Finding determinants of audit delay by pooled OLS regression analysis. Croatian Operational Research Review, 81-91.

Widhiasari, N. M. S., \& Budiartha, I. K. (2016). Pengaruh Umur Perusahaan, Ukuran Perusahaan, Reputasi Auditor, Dan Pergantian Auditor Terhadap Audit Report Lag. E-Jurnal Akuntansi, 15(1), 200-228.

Yuniarti, R. (2018). Rina Yuniarti Pengaruh Likuiditas, Ukuran Perusahaan Dan Reputasi KAP. Baabu Al-Ilmi, 1, 127-145. 